\title{
Can stakeholders agree on how to reduce human- carnivore conflict on Namibian livestock farms? A novel Q-methodology and Delphi exercise
}

NIKI A. RUST

\begin{abstract}
Conflict between carnivores and livestock farmers affects human livelihoods and predator populations. Historically, successful mitigation of this conflict has been limited, sometimes because of a lack of participation among stakeholders to create and implement agreeable and effective solutions. Finding common ground between stakeholders can, however, be difficult, partly because of the range and intensity of values held. Using a novel combination of Q-methodology and the Delphi technique, I investigated whether a diverse range of stakeholders could agree on how to mitigate conflict between carnivores and livestock farmers in Namibia. A strong consensus was reached on using conservation education and husbandry training to reduce livestock depredation. Two narratives emerged: one group preferred non-lethal methods to manage the conflict, whereas a smaller group preferred lethal measures. This new decision-making exercise has potential to be applied to other conservation conflicts to assist with participatory decision making.
\end{abstract}

Keywords Carnivores, consensus building, decision making, Delphi technique, human-wildlife conflict, livestock depredation, Q-methodology

\section{Introduction}

C onflict between carnivores and livestock farmers threatens predator populations and farmers' livelihoods (Loveridge et al., 2010; Rust \& Marker, 2014). This conflict is difficult to resolve, partly because of complex social disagreements on governance options and goals (Clark et al., 2014). To reduce the problem effectively requires focusing on mitigating conflict not only between people and predators but also between various groups of people (Redpath et al., 2015).

Historically, conservation of threatened species such as carnivores involved little participation from the local communities that were affected by wildlife management decisions (Brockington, 2002). This lack of participation can create tensions between stakeholders regarding how to mitigate the situation effectively (Thirgood \& Redpath, 2008),

NIKI A. RUST (Corresponding author) Durrell Institute of Conservation and Ecology, University of Kent, Canterbury CT2 7NR, UK

E-mail niki_rust@hotmail.co.uk

Received 21 July 2015. Revision requested 16 September 2015.

Accepted 22 September 2015. First published online 25 January 2016. which can sometimes result in communities revolting against management decisions (Goldman et al., 2013). It is seen as increasingly important for wildlife managers to cooperate with the communities that share land with wildlife, and to involve them in management decisions. Community engagement has the potential to foster more amicable relations between all parties, which can lead to more socially accepted and sustainable management plans (Kittinger et al., 2012).

This study focuses on human-predator conflict in Namibia, where carnivore populations have been increasing in recent decades, causing more frequent livestock depredation (NACSO, 2013). Official management of human-wildlife conflict is overseen by the government but the policy focuses almost exclusively on communal farmers who live on government land, and largely ignores freehold commercial farmers (Government of Namibia, 2009). Because of this skewed governance it is legal for commercial farmers to kill carnivores on their land if deemed a threat to human lives or property (Government of Namibia, 1975). This conflict requires immediate attention to ensure minimal damage to farmers' livelihoods and recently restored carnivore populations. Creating a participatory management plan could help to solve this problem.

Previous research elsewhere that has used participatory decision making to manage predators has sometimes found a lack of common ground between stakeholder groups (Redpath et al., 2004; Johnson \& Sciascia, 2013). This lack of agreement could stall management progress or inflame conflict between groups. Namibia is no exception, and the issue is further complicated by divergent stakeholder opinions on managing carnivores (Mosimane et al., 2014; Rust, 2015a). As many carnivore species range beyond farm boundaries it is essential that farmers manage carnivores collectively.

This study used a novel participatory decision-making exercise to determine (1) whether stakeholders could agree on ways to mitigate human-carnivore conflict on commercial livestock farms in Namibia, and (2) whether there were separate groups of participants who had similar or conflicting viewpoints on preferred management plans.

\section{Methods}

The decision-making technique

This study employed an innovative combination of the Delphi technique and Q-methodology. The Delphi 
technique is a systematic, iterative process of decision making in which experts can form consensus on how to tackle a complex problem (Dalkey, 1972). The main benefit of using this method is that it is completed anonymously, which can encourage honest discussion, lower inhibitions (Hess \& King, 2002) and reduce power differentials between participants (Dalkey, 1972). The iterative nature facilitates learning, potentially resulting in a more informed decision (Hung et al., 2008), and can also break down barriers between conflicting stakeholders when they realize that opposing groups potentially hold similar views to their own.

Q-methodology is a structured quantitative interview where participants are asked to rank predefined statements on a scale (Stephenson, 1953; Brown, 1980). It 'considers people as whole entities and correlates individuals instead of traits' (Byrd, 2002, p. 52). This technique is particularly suited to studying complex phenomena in which individuals hold contrasting views (Barry \& Proops, 1999), and can reveal areas of statistical consensus and disagreement, as well as uncover distinct narratives amongst participants. Consequently, it could be useful in facilitating understanding of heterogeneous stakeholder views on human-wildlife conflict (Johnson \& Sciascia, 2013). It does not require a large or random sample size, as participants are chosen based upon reaching theoretical saturation in terms of the possible range of views on a topic (Stephenson, 1953), and therefore external validity cannot be conferred. However, the aim of Q-methodology is to determine the range rather than the frequency of views (Johnson \& Sciascia, 2013).

As the Delphi technique does not seek to address the subjectivity in decision making it could be useful to combine it with Q-methodology. This blend would give rise to a participatory decision-making tool that includes group feedback and repeated rounds, potentially resulting in statistical consensuses and disagreements, and/or various narratives for solving a problem. Deliberation and feedback of results could lead to a more holistic and rational decision, rather than quick, instinctive decisions that might not have considered fully all available options and outcomes (Dalkey, 1969).

\section{Q-methodology statement collection}

Q-methodology requires an initial data collection period to develop the concourse (i.e. the diversity of views on a phenomenon). Content analysis of Namibian newspapers was used to collect some of the concourse statements on the types of mitigation techniques used to reduce conflict with carnivores and livestock farmers in the country. Five of the main English-language newspapers were used in content analysis: Informante, The Namibian, Namibia Economist, Namibian Sun and New Era. Articles were screened by searching for the keywords 'carnivore', 'predator', 'human-wildlife conflict' and 'depredation'. Content analysis was also used to identify the main stakeholder groups involved in Namibian carnivore management, which informed later sampling for the Delphi/Q.

Interviews were also used to collect additional concourse statements and were conducted with 45 participants: 22 farmers, seven conservationists, five government officials, four tourism operators, three landowners offering trophy hunting, two meat industry workers and two academics. Conducted in English (the official language of Namibia), a semi-structured format was used and interviews typically lasted 1 hour. Questions related to how participants would like to manage carnivores on Namibian commercial farmland, what methods they thought were and were not effective, and what methods they would recommend using.

In total, 50 statements on how to mitigate conflict were collected from the interviews and 78 from newspaper articles. These were refined to 34 by deleting duplicates and combining those that were similar. These 34 statements comprised the concourse for use in the Q-methodology (Table 1), which retained the original wording to capture the intent of the source (Rastogi et al., 2013).

\section{Sampling}

As random sampling is not necessary for either Delphi or Q (Brown, 1980; Skulmoski et al., 2007), participants were purposefully sampled to ensure breadth and diverse representation across stakeholder groups, to capture the range of possible views on conflict mitigation (Brown, 1980). Snowball sampling was used to increase the sample size and ensure theoretical saturation.

A total of 54 potential participants were contacted via email to request their participation in the Q/Delphi exercise. These included all individuals that had participated in the initial interview and those who had been identified through purposeful and snowball sampling. Thirty-five participants (the P-set) completed the first online survey (66\% response rate): 14 livestock farmers, six conservationists, six landowners offering trophy hunting, five meat industry employees, two tourism operators and two environmental academics. Emphasis was placed on livestock farmers because they are the stakeholders that currently have the power to manage carnivores on farmland. The same 35 participants were sent the second survey 1 month later, of which 32 completed the survey. Twenty-nine of the 35 completed the third and final survey, of which 11 were farmers, six conservationists, five landowners offering trophy hunting, four meat employees, two tourism operators and one an environmental academic.

\section{Q-sort and Delphi}

A Q-sort refers to the participant-ranked concourse statements. An online survey tool (SurveyMonkey, 2015) was used to administer the Q-sort. Prior to implementation, a pilot of the 
TABLE 1 Q-sort statements used during Delphi rounds, with corresponding $z$ scores (underlined values reflect areas of statistical consensus).

\begin{tabular}{|c|c|c|c|c|c|c|c|}
\hline \multirow[b]{2}{*}{ Statement no. } & \multirow[b]{2}{*}{$\begin{array}{l}\text { Statement to mitigate conflict between large } \\
\text { carnivores \& livestock farmers }\end{array}$} & \multicolumn{2}{|c|}{ Round $1 z$-score } & \multicolumn{2}{|c|}{ Round $2 z$-score } & \multicolumn{2}{|c|}{ Round $3 z$-score } \\
\hline & & $\begin{array}{l}\text { Factor A } \\
(\mathrm{n}=24)\end{array}$ & $\begin{array}{l}\text { Factor } \mathrm{B} \\
(\mathrm{n}=11)\end{array}$ & $\begin{array}{l}\text { Factor C } \\
(\mathrm{n}=19)\end{array}$ & $\begin{array}{l}\text { Factor D } \\
(\mathrm{n}=11)\end{array}$ & $\begin{array}{l}\text { Factor } \mathrm{E} \\
(\mathrm{n}=21)\end{array}$ & $\begin{array}{l}\text { Factor } \mathrm{F} \\
(\mathrm{n}=6)\end{array}$ \\
\hline 1 & $\begin{array}{l}\text { Compensate farmers for full value of livestock } \\
\text { killed by predators }\end{array}$ & $-1^{\star}$ & 0 & $-\underline{2}$ & $-\underline{1}$ & $-\underline{2}$ & $-\underline{1}$ \\
\hline 2 & $\begin{array}{l}\text { Promote photo tourism as a way to receive in- } \\
\text { come from predators }\end{array}$ & $1^{*}$ & 0 & $1^{\star}$ & 0 & $1^{\star}$ & $-\underline{1}$ \\
\hline 3 & $\begin{array}{l}\text { Promote trophy hunting of predators as a way to } \\
\text { be reimbursed for livestock loss }\end{array}$ & $-1^{\star}$ & 2 & $-\underline{1}$ & $\underline{0}$ & $\underline{0}$ & $\underline{0}$ \\
\hline 4 & $\begin{array}{l}\text { Farmers should receive a price premium if meat } \\
\text { is farmed in a 'predator-friendly' way }\end{array}$ & $2^{*}$ & 0 & $2^{*}$ & 0 & 1 & 0 \\
\hline 5 & $\begin{array}{l}\text { Use profits from nature reserves \& Game Trust } \\
\text { Fund to fund management of predators in } \\
\text { nearby areas }\end{array}$ & $\underline{0}$ & $\underline{1}$ & $\underline{0}$ & $\underline{0}$ & 0 & $-\underline{1}$ \\
\hline 6 & $\begin{array}{l}\text { Count livestock often for human presence to } \\
\text { deter predators and also to find lost livestock }\end{array}$ & 3 & 1 & $\underline{1}$ & $\underline{1}$ & $0^{*}$ & 2 \\
\hline 7 & Kill predators that kill livestock & $-2^{*}$ & 3 & $-2^{*}$ & 3 & $-2^{*}$ & 3 \\
\hline 8 & $\begin{array}{l}\text { Properly fence national parks \& hunting re- } \\
\text { serves to stop predators from escaping }\end{array}$ & $\underline{0}$ & $\underline{0}$ & $0^{*}$ & 2 & $\underline{1}$ & $\underline{1}$ \\
\hline 9 & $\begin{array}{l}\text { Monitor numbers of predators to set more } \\
\text { accurate hunting quotas }\end{array}$ & $\underline{2}$ & $\underline{1}$ & $1^{*}$ & 2 & $\underline{1}$ & $\underline{0}$ \\
\hline 10 & $\begin{array}{l}\text { Use livestock-guarding animals to protect stock } \\
\text { from predators }\end{array}$ & $\underline{2}$ & $\underline{1}$ & $\underline{2}$ & $\underline{1}$ & 2 & 1 \\
\hline 11 & $\begin{array}{l}\text { Train farm workers on how to protect livestock } \\
\text { from predators \& how to improve livestock } \\
\text { management }\end{array}$ & $\underline{3}$ & $\underline{2}$ & $\underline{3}$ & $\underline{3}$ & $\underline{3}$ & $\underline{3}$ \\
\hline 12 & $\begin{array}{l}\text { Zone areas where conflict is highest, \& target } \\
\text { with mitigation measures }\end{array}$ & $1^{\star}$ & 3 & $0^{*}$ & 1 & 0 & 1 \\
\hline 13 & $\begin{array}{l}\text { Put livestock in kraals overnight to protect from } \\
\text { predators \& always keep vulnerable livestock in } \\
\text { kraals }\end{array}$ & $1^{*}$ & -1 & $1^{*}$ & -1 & $1^{\star}$ & -2 \\
\hline 14 & $\begin{array}{l}\text { Employ herders to protect livestock from } \\
\text { predators }\end{array}$ & $1^{*}$ & 0 & 1 & 0 & $\underline{2}$ & $\underline{1}$ \\
\hline 15 & $\begin{array}{l}\text { Pay compensation for killed livestock to people } \\
\text { who have taken active steps to avoid depredation }\end{array}$ & $1^{\star}$ & -1 & $1^{*}$ & -1 & $0^{*}$ & -1 \\
\hline 16 & $\begin{array}{l}\text { Teach people about conservation, ecology, value } \\
\text { of predators \& identification of cause of live- } \\
\text { stock death }\end{array}$ & $\underline{3}$ & $\underline{2}$ & $\underline{3}$ & $\underline{2}$ & $\underline{3}$ & $\underline{2}$ \\
\hline 17 & Sell problem predators to nature reserves \& zoos & 0 & 1 & $0^{*}$ & 1 & $\underline{0}$ & $\underline{0}$ \\
\hline 18 & $\begin{array}{l}\text { Reduce consumption of wild meat to increase } \\
\text { wild prey for predators }\end{array}$ & $-\underline{2}$ & $-\underline{2}$ & $-\underline{2}$ & $-\underline{2}$ & $-\overline{2}$ & $-\overline{3}$ \\
\hline 19 & $\begin{array}{l}\text { Change from small stock to cattle farming in } \\
\text { areas with many small predators }\end{array}$ & $-1^{\star}$ & -3 & $-1^{\star}$ & -3 & $-1^{*}$ & -2 \\
\hline 20 & $\begin{array}{l}\text { Install predator-proof fencing around grazing } \\
\text { camps }\end{array}$ & $-2^{*}$ & 1 & $-1^{*}$ & 1 & $-1^{*}$ & 0 \\
\hline 21 & Kill all predators that enter farm & $-3^{*}$ & -1 & $-3^{*}$ & -2 & $-3^{*}$ & 0 \\
\hline 22 & $\begin{array}{l}\text { Use indigenous breeds of livestock with horns to } \\
\text { protect against predators }\end{array}$ & $0^{*}$ & -2 & $\underline{0}$ & $\underline{0}$ & $\underline{1}$ & $\underline{1}$ \\
\hline 23 & $\begin{array}{l}\text { Allow restricted hunting of problem lions \& } \\
\text { wild dogs }\end{array}$ & $0^{*}$ & 2 & $0^{*}$ & 1 & $0^{*}$ & 2 \\
\hline 24 & $\begin{array}{l}\text { Keep a couple of large predators on a farm to } \\
\text { control jackal \& caracal populations }\end{array}$ & $0^{*}$ & -3 & $-1^{*}$ & -2 & $-1^{\star}$ & -2 \\
\hline 25 & $\begin{array}{l}\text { Pay farmers for the number of predators on } \\
\text { their farms (more predators }=\text { more money) }\end{array}$ & $-2^{*}$ & -3 & $-1^{*}$ & -2 & $-1^{*}$ & -3 \\
\hline 26 & $\begin{array}{l}\text { Allow sale of skin of hunted problem predator to } \\
\text { reimburse for loss of livestock }\end{array}$ & $-1^{*}$ & 3 & $-1^{*}$ & 2 & $-1^{\star}$ & 2 \\
\hline 27 & $\begin{array}{l}\text { Have a government-run livestock breeding } \\
\text { centre to replace predator-killed livestock }\end{array}$ & -3 & -2 & $-\underline{2}$ & $-\underline{3}$ & $-\underline{2}$ & $-\underline{1}$ \\
\hline
\end{tabular}


Table 1 (Cont.)

\begin{tabular}{|c|c|c|c|c|c|c|c|}
\hline \multirow[b]{2}{*}{ Statement no. } & \multirow[b]{2}{*}{$\begin{array}{l}\text { Statement to mitigate conflict between large } \\
\text { carnivores \& livestock farmers }\end{array}$} & \multicolumn{2}{|c|}{ Round $1 z$-score } & \multicolumn{2}{|c|}{ Round $2 z$-score } & \multicolumn{2}{|c|}{ Round $3 z$-score } \\
\hline & & $\begin{array}{l}\text { Factor A } \\
(\mathrm{n}=24)\end{array}$ & $\begin{array}{l}\text { Factor B } \\
(\mathrm{n}=11)\end{array}$ & $\begin{array}{l}\text { Factor C } \\
(\mathrm{n}=19)\end{array}$ & $\begin{array}{l}\text { Factor D } \\
(\mathrm{n}=11)\end{array}$ & $\begin{array}{l}\text { Factor } \mathrm{E} \\
(\mathrm{n}=21)\end{array}$ & $\begin{array}{l}\text { Factor } \mathrm{F} \\
(\mathrm{n}=6)\end{array}$ \\
\hline 28 & $\begin{array}{l}\text { Reward farmers (in cash \& by recognition) when } \\
\text { they have no livestock loss or use predator- } \\
\text { friendly methods }\end{array}$ & $0^{*}$ & -1 & $0^{*}$ & -1 & 0 & 0 \\
\hline 29 & $\begin{array}{l}\text { Pilot a predator-friendly farm to train farmers } \\
\text { how to coexist with predators }\end{array}$ & $1^{*}$ & -1 & $2^{*}$ & 1 & $2^{*}$ & -1 \\
\hline 30 & $\begin{array}{l}\text { Employ 'environmental shepherds' who look } \\
\text { after livestock \& monitor for poaching, cattle } \\
\text { theft \& wildlife numbers }\end{array}$ & $2^{*}$ & 0 & $2^{*}$ & 0 & $\underline{2}$ & $\underline{1}$ \\
\hline 31 & $\begin{array}{l}\text { Put radio collars on predators; if they are proven } \\
\text { to kill stock, kill that animal }\end{array}$ & $-\underline{1}$ & $\underline{0}$ & $-\underline{1}$ & $-\underline{1}$ & -1 & 0 \\
\hline 32 & $\begin{array}{l}\text { Provide subsidies to farmers who kraal calves/ } \\
\text { kids/lambs or use herders }\end{array}$ & $-\underline{1}$ & $-\underline{1}$ & $0^{\star}$ & -1 & $-1^{*}$ & -2 \\
\hline 33 & $\begin{array}{l}\text { Move female livestock with young to areas } \\
\text { without predators and swap with farms that } \\
\text { have adult males in areas with good grazing but } \\
\text { no predators }\end{array}$ & $0^{*}$ & -2 & $\underline{0}$ & $\underline{0}$ & $\underline{0}$ & $\underline{0}$ \\
\hline 34 & $\begin{array}{l}\text { Only allow predators to survive in protected } \\
\text { areas }\end{array}$ & $-3^{\star}$ & 0 & $-3^{*}$ & -1 & $-3^{*}$ & 0 \\
\hline 35 & Use high-density herds \& move them frequently & - & - & $\underline{0}$ & $\underline{0}$ & $0^{*}$ & 1 \\
\hline 36 & $\begin{array}{l}\text { Improve habitat for game to thrive so popula- } \\
\text { tions increase \& predators prefer to kill wild } \\
\text { game }\end{array}$ & - & - & $\underline{1}$ & $\underline{0}$ & $1^{*}$ & -1 \\
\hline
\end{tabular}

${ }^{*}$ Denotes significant difference between the two factors.

Q/Delphi survey was administered to eight volunteers (four within and four external to the study site) to determine the ease of completing the survey, whether the statements were clear and whether the instructions were comprehensible.

In the survey, participants were asked to rank each mitigation method on a 7-point Likert scale ranging from -3 (strongly disagree) to 3 (strongly agree). At the end of each survey participants were asked about their reasons for strongly agreeing or disagreeing with statements to gain information on the subjective reasoning behind their selections. At the end of the first round, participants were also asked to recommend other statements that should be included in the subsequent rounds, and this resulted in the inclusion of two more statements ( 35 and 36; Table 1). Each Q-sort was conducted monthly, in three iterations during October-December 2013. At the end of each round an email was sent to participants listing the three most and least popular statements from that round, which comprised part of the Delphi group informed feedback.

\section{Analyses}

The Q-sort analysis was run in PQMethod v. 2.33 (Schmolck, 2002). The analysis determined (1) whether participants reached agreement on any of the proposed mitigation measures and (2) whether there were groups of participants who ranked statements in a statistically similar manner. Initially the data were run through a principal component analysis to identify loaded factors (i.e. groups of participants who ranked statements similarly; Buckley, 2012). These factors went through Varimax rotation, which determined the most parsimonious structure that explained the highest variability between factor groups (Brown, 1980). PQMethod arranged the Q-sorts into the factors that were most correlated. Factors with eigenvalues $>_{1}$ (Webler et al., 2009) were put into a factor analysis. Each statement was given a $z$-score based on the mean rank given by participants within each factor. Statistical consensus was defined where $\mathrm{P}>0.01$ (i.e. groups of participants did not rank statements differently at the $99 \%$ confidence level). For the statements that were statistically consensual a strong agreement was defined where the mean rank between factors was at least +2 or -2 . A grounded theory approach was used to qualitatively analyse answers to the open-ended questions, where common themes were searched for and coded in the data (Strauss \& Corbin, 1990). Quotes used in the results section were selected for their typical representation of a particular theme (Auerbach \& Silverstein, 2003). 


\section{Results}

Overall, participants agreed throughout the three Delphi rounds that human-carnivore conflict could be mitigated firstly by training farm workers in effective husbandry to deter predators and secondly by teaching people about conservation of predators (Table 1). Participants also strongly agreed that conflict would not be resolved by reducing consumption of wild game meat.

Despite consensus, Q-methodology separated two factors (or narratives) in each Delphi round (Table 1). Participants in the first narrative (factors A, C, E; Table 1) remained positive regarding non-lethal methods to mitigate conflict (statements 10,16 and 30) and negative regarding lethal methods and having a government-run livestock breeding centre to replace livestock killed by predators (statements 7, 21, 27 and 34); this group is therefore called the non-lethal narrative. The second narrative $(\mathrm{B}, \mathrm{D}, \mathrm{F})$ had participants who remained positive regarding training, lethal control and consumptive use (statements 7, 23 and 26) and negative regarding economic incentives and changing from small stock to cattle farming (statements 15, 19, 24, 25 and 32); this group is called the lethal narrative. In general, the non-lethal narrative consisted of conservationists, academics, trophy hunters and cattle farmers, whereas the lethal narrative included sheep farmers and meat industry employees. By the final round, $63 \%$ of all livestock farmer participants loaded into the non-lethal narrative.

Factor analysis of Round 1 produced two factors that explained $51 \%$ of the variance $(38 \%$ for factor $\mathrm{A}$ and $13 \%$ for factor $\mathrm{B})$. The statements, their mean ranking and the areas of agreement and disagreement are shown in Table 1. Participants in factor A (the non-lethal narrative) were defined by agreeing to statements that improved livestock husbandry (statements 4, 13, 30) and disagreeing that predators should only survive in protected areas (statement 34). Conversely, participants in factor B (the lethal narrative) were critical of solutions that involved allowing carnivores to live on farms (statements 24 and 25) and agreed with consumptive use of carnivores (statements 3, 23, 26) but disagreed with changing livestock management practices (statements 13, 22, 33). A strong agreement was reached in Round 1 on statements 11 (training farm workers on how to look after livestock when predators are present) and 16 (teaching people about ecology and the value of predators) as the most acceptable methods to resolve conflict. For statements 18 (reduce wild meat consumption), 25 (pay farmers for the number of predators on their farm) and 27 (have a livestock replacement centre) both factors agreed that these methods would not reduce conflict.

Factor analysis of data from Round 2 produced two factors that explained $45 \%$ of the variance $(35 \%$ for factor C, $10 \%$ for factor D). Factor C (the non-lethal narrative) voted in favour of price premiums on predator-friendly meats (statement 4), whereas factor D (the lethal narrative) voted against this. Participants loading onto both factors were more positive about piloting a predator-friendly farm (statement 29) compared with Round 1, although the nonlethal narrative was consistently more positive about this method than the lethal narrative. A strong agreement was reached on the same statements as in Round 1, but views on paying for the number of predators on farms were less negative in this round (statement 25).

Factor analysis of Round 3 again produced two factors that explained $57 \%$ of the variance $(37 \%$ for factor E, $20 \%$ for factor F). A strong agreement was reached on statements 11 (training farm workers in more effective husbandry) and 16 (teaching people about conservation and value of predators) and there was strong disagreement with statement 18 (reducing wild meat consumption) as ways to mitigate conflict.

\section{Participants' reasoning for their answers}

The comments made by participants at the end of each round helped to explain the subjective reasoning behind their voting behaviour. Education in predator conservation and training on livestock husbandry were thought by many participants to be the most effective ways to mitigate conflict because 'only if you know enough about nature you can react against it' (cattle and sheep farmer $\mathrm{CS}_{2}$ ). Participants were against the idea of reducing consumption of game meat to increase wild prey for carnivores, believing that 'wild meat feeds the nation' (cattle farmer $\mathrm{CT}_{9}$ ).

In general, participants were critical of compensation payments, as they questioned 'who will finance compensation for killed livestock? Sounds good, but who has the money and will be willing to administrate it on a sustainable basis?' (cattle farmer $\mathrm{CT}_{3}$ ), nor did they like the idea of a government-run livestock replacement centre, as the government 'will not breed what I want and animals might be less adapted' (cattle farmer CT6). Furthermore, participants thought that the government should not be involved in managing economic incentives: 'I do not believe that any (governmental) interventions into private business (i.e. livestock farming) will work out, as administration and control thereof will be too complicated and also some farmers will try to screw the system to earn extra money' (sheep farmer $\mathrm{SF}_{2}$ ).

Most participants in the non-lethal narrative, which included many of the farmers, appeared to show some tolerance towards predators. They often mentioned that predators should not be eliminated because they 'are part of nature and the ecology and have a definitive place therein' (cattle farmer $\mathrm{CT}_{7}$ ) and 'are essential in the food chain' (cattle farmer $\mathrm{CT}_{1}$ ). Participants were often wary of economic incentives ('I do not always agree that money solves the 
problems'; tourism operator $\mathrm{TO}_{2}$ ) but believed that conflict could be reduced effectively through education and experience: 'most problems occur because of lack of knowledge. Only knowledge can improve management' (cattle farmer CT10). Economic incentives were often considered to be a short-term fix but not a long-term solution.

Conversely, the lethal control narrative believed culling predators was important because carnivores 'need to be controlled, especially those who kill livestock' (cattle and sheep farmer $\mathrm{CS}_{1}$ ). This narrative was critical of changing management practices because they thought this was unfeasible: 'it is no solution to highly restrict (the way of) livestock farming or make it impossible' (sheep farmer $\mathrm{SF}_{1}$ ). Herding was not considered practical because of its 'major rangeland impacts' (trophy hunter TH2). The lethal control narrative was in favour of ensuring predators remained only in protected areas: 'There is enough land in Namibia for predators, why must the commercial farmers also keep them?' (cattle farmer $\mathrm{CT}_{3}$ ). Participants in this narrative also thought it made sense to receive income from killing predators, as this could offset the cost of depredation: 'Reimbursing farmers who have losses due to predators is very good and through trophy [hunting] some funds can be generated' (meat board employee $\mathrm{MB}_{2}$ ).

\section{Discussion}

The results show that stakeholders reached a strong agreement on some techniques to reduce human-carnivore conflict in Namibia. They agreed that training farm workers to improve their livestock husbandry and teaching people about carnivores could reduce conflict. Farm workers in Namibia tend to be from poor backgrounds and have limited education (Hunter, 2004), and therefore it is possible that educating them about effective husbandry will benefit the situation (Rust, 2015b). Previous research has shown that increased knowledge of carnivores and livestock husbandry practices can increase tolerance and reduce livestock depredation on Namibian farms (Marker et al., 2003), thus the Delphi/Q-methodology has successfully highlighted areas of agreement that reflect effective solutions to mitigating human-wildlife conflict.

Along with a consensus on how conflict should be mitigated, there was also agreement on how it should not be managed; i.e. through reducing wild game meat consumption. This statement was suggested initially on the basis that it could increase the availability of wild prey for carnivores and thereby potentially limit livestock depredation (Inskip \& Zimmermann, 2009). However, participants opposed this idea because game meat was seen as a benefit accrued by the majority of Namibians, as most farmers hunt game animals for their own consumption and/or for sale to the general public. Wild meat is also used as part-payment of salaries for farm workers and has significant cultural value (Botha, 2005; Karamata, 2006). Thus it may not be culturally or economically feasible to introduce this mitigation method in Namibia.

The results show more areas of consensus between stakeholder groups than other similar predator management studies (e.g. Redpath et al., 2004; Johnson \& Sciascia, 2013). It is not clear why this is the case; it may be because of the method used or because conflict between stakeholders is less heated in Namibia compared with other areas. This less intense conflict could be an important factor in creating positive collaborations between stakeholder groups for collectively managing carnivores.

Despite there being areas of agreement, two different viewpoints on how to mitigate negative human-carnivore interactions on livestock farms emerged. However, the divide is not as simple as conservationists preferring non-lethal solutions and farmers preferring lethal control of carnivores. On the contrary, two-thirds of livestock farmer participants opposed lethal control, which contrasts with research findings elsewhere (Selebatso et al., 2008; Schumann et al., 2012). It is unclear why this is the case here, particularly as the survey was undertaken anonymously and therefore there was no pressure on participants to conform to social norms (Dalkey, 1972). It may be that long-standing education on carnivores in Namibia has slowly improved attitudes and behaviour towards predators (Marker et al., 2003) or that the sample size was too small to notice negative attitudes towards carnivores. This confirms the finding of Chamberlain et al. (2012) that it should not be assumed that individuals within a stakeholder group hold uniform opinions on wildlife management (i.e. that all farmers are anti-carnivore) but rather the differences of opinion are more complex, and consensus can be found between diverse stakeholder groups.

For the lethal control narrative management changes on the farm were not considered to be potential solutions to the conflict. Conforti \& Azevedo (2003) also found that some farmers were unwilling to improve their husbandry practices to reduce depredation. Farmers in general are risk averse and do not tend to change their management unless absolutely necessary (Binswanger \& Sillers, 1983). It may therefore be inappropriate to advise conservative farmers on changing their management.

Economic incentives, particularly those offered by the government, were not a preferred conflict mitigation method as participants feared corruption and incompetence, in accordance with previous findings (Dickman et al., 2011; Rust, 2015a). Photographic tourism was not considered to be effective at reducing conflict as participants felt it was too difficult to ensure that guests could view rare and illusive carnivores. There was also concern about having strangers on farms, which interfered with the peace and solitude desired by some farmers. On a deeper level, this suggests that money may not be the sole motivator in decision making; 
happiness depends on many other values besides monetary wealth (Myers \& Diener, 1996).

Using Delphi and Q-methodology together may have helped reduce conflict and power differentials between participants, which usually hinder successful decision making in face-to-face negotiations (Susskind et al., 2003). This may have been one of the reasons why more participants reached consensus in this study compared with other studies. Remote methods of decision making may therefore be useful when integrating participant views from conflicting stakeholder groups, such as is usually the case in humanwildlife conflict situations. However, participating remotely might have hampered social learning (Ziglio, 1996), emotional attachment and empathy building, which are important aspects of decision making (Wieczorek Hudenko, 2012). I therefore recommend that participants attend a workshop at the final round to facilitate communication between participants.

Undertaking the Q/Delphi online in English could have limited the number of participants involved, but most Namibian commercial farmers are well educated (at least half have a university degree; Olbrich et al., 2012). They are also required to use computers as part of record keeping and financial management, and therefore they are usually computer literate and have access to the Internet (NR, pers. obs.). A future study could include surveys in various languages and via other media to ensure participation is as inclusive as possible. Although this method was relatively inexpensive to conduct (the online survey and content analysis were free to run), the process of collecting concourse statements and conducting the three Delphi rounds was time-consuming (6 months in total). If decisions need to be made quickly, this method may not be appropriate. The final limitation to this method is that, because of the sampling procedure used, results cannot be inferred more widely. If this method were to be used to inform policy, a larger sample size using random sampling would be needed.

In summary, combining Delphi and Q-methodology to understand whether stakeholders could agree on how to mitigate carnivore conflict on commercial farms in Namibia revealed some consensus regarding potential management policies, as well as areas of disagreement. This novel method could be used in other areas of participatory decision making for wildlife management, to legitimize the process and reduce conflicts between groups. The fact that the technique required participants to interact remotely and anonymously was probably a key factor in ensuring that conflict between stakeholders did not hinder the process. It may therefore be important for participants to reach agreement remotely, at least during the first few rounds. The suggested mitigation methods can be used as a starting point to help develop a socially accepted carnivore management plan that will assist in reducing conflict between people and carnivores in Namibia.

\section{Acknowledgements}

This work was sponsored by the Economic \& Social Research Council (grant number 12906529), Panthera Kaplan Graduate Award and Okonjima Nature Reserve/ AfriCat Foundation. I thank especially H. \& B. Sohrada and S. Redpath.

\section{References}

Auerbach, C.F. \& Silverstein, L.B. (2003) Qualitative Data: An Introduction to Coding and Analysis. New York University Press, New York, USA.

BARRY, J. \& Proops, J. (1999) Seeking sustainability discourses with Q methodology. Ecological Economics, 28, 337-345.

Binswanger, H.P. \& Sillers, D.A. (1983) Risk aversion and credit constraints in farmers' decision-making: a reinterpretation. The Journal of Development Studies, 20, 5-21.

Bотна, C. (2005) People and the environment in colonial Namibia. South African Historical Journal, 52, 170-190.

Brockington, D. (2002) Fortress Conservation: The Preservation of the Mkomazi Game Reserve, Tanzania. Indiana University Press, Bloomington, USA.

Brown, S.R. (1980) Political Subjectivity: Applications of Q Methodology in Political Science. Yale University Press, New Haven, USA.

BUCKLEY, C. (2012) Implementation of the EU Nitrates Directive in the Republic of Ireland-a view from the farm. Ecological Economics, 78, 29-36.

BYRD, K. (2002) Mirrors and metaphors: contemporary narratives of the wolf in Minnesota. Ethics, Place \& Environment, 5, 50-65.

Chamberlain, E.C., Rutherford, M.B. \& Gibeau, M.L. (2012) Human perspectives and conservation of grizzly bears in Banff National Park, Canada. Conservation Biology, 26, 420-431.

Clark, S.G., Rutherford, M.B. \& Mattson, D.J. (2014) Large carnivores, people, and governance. In Large Carnivore Conservation: Integrating Science and Policy in the North American West (eds S.G. Clark \& M.B. Rutherford), pp. 1-28. University of Chicago Press, Chicago, USA.

Conforti, V.A. \& de Azevedo, F.C.C. (2003) Local perceptions of jaguars (Panthera onca) and pumas (Puma concolor) in the Iguaçu National Park area, south Brazil. Biological Conservation, 111, 215-221.

Dalkey, N. (1969) The Delphi Method: An Experimental Study of Group Opinion. The RAND Corporation, Santa Monica, USA.

Dalkey, N. (1972) Studies in the Quality of Life: Delphi and Decision-Making. Lexington Books, Lanham, USA.

Dickman, A.J., Macdonald, E.A. \& Macdonald, D.W. (2011) A review of financial instruments to pay for predator conservation and encourage human-carnivore coexistence. Proceedings of the National Academy of Sciences of the United States of America, 108, 13937-13944.

Goldman, M.J., Roque de Pinho, J. \& Perry, J. (2013) Beyond ritual and economics: Maasai lion hunting and conservation politics. Oryx, 47, 490-500.

Government of Namibia (1975) Nature Conservation Ordinance, 1975. Windhoek, Namibia.

Government of Namibia (2009) National Policy on HumanWildlife Conflict Management 2009. Directorate of Parks and Wildlife Management, Windhoek, Namibia. 
Hess, G.R. \& King, T.J. (2002) Planning open spaces for wildlife: I. Selecting focal species using a Delphi survey approach. Landscape and Urban Planning, 58, 25-40.

Hung, H.-L., Altschuld, J.W. \& Lee, Y.-F. (2008) Methodological and conceptual issues confronting a cross-country Delphi study of educational program evaluation. Evaluation and Program Planning, 31, 191-198.

Hunter, J. (2004) Who Should Own the Land? Analysis and Views on Land Reform and the Land Question in Namibia and South Africa. Konrad-Adenauer-Stiftung and Namibia Institute for Democracy, Windhoek, Namibia.

Inskip, C. \& Zimmermann, A. (2009) Human-felid conflict: a review of patterns and priorities worldwide. Oryx, 43, 18-34.

JoHnson, B.B. \& SCIASCiA, J. (2013) Views on black bear management in New Jersey. Human Dimensions of Wildife, 18, 249-262.

Karamata, C. (2006) Farm Workers in Namibia: Living and Working Conditions. Labour Resource and Research Institute, Windhoek, Namibia.

Kittinger, J.N., Bambico, T.M., Watson, T.K. \& Glazier, E.W. (2012) Sociocultural significance of the endangered Hawaiian monk seal and the human dimensions of conservation planning. Endangered Species Research, 17, 139-156.

Loveridge, A.J., Wang, S.W., Frank, L.G. \& Seidensticker, J. (2010) People and wild felids: conservation of cats and management of conflicts. In Biology and Conservation of Wild Felids (eds D. W. Macdonald \& A.J. Loveridge), pp. 161-195. Oxford University Press, Oxford, UK.

Marker, L.L., Mills, M.G.L. \& Macdonald, D.W. (2003) Factors influencing perceptions of conflict and tolerance toward cheetahs on Namibian farmlands. Conservation Biology, 17, 1290-1298.

Mosimane, A.W., McCool, S., Brown, P. \& Ingrebretson, J. (2014) Using mental models in the analysis of human-wildlife conflict from the perspective of a social-ecological system in Namibia. Oryx, 48, 64-70.

Myers, D.G. \& Diener, E. (1996) The pursuit of happiness. Scientific American, 274, 70-72.

NACSO (2013) The State of Community Conservation in Namibia-A Review of Communal Conservancies, Community Forests and other CBNRM Initiatives (2012 Annual Report). NACSO, Windhoek, Namibia.

Olbrich, R., QuAas, M.F. \& BAUmgäRTNeR, S. (2012) Characterizing commercial cattle farms in Namibia: risk, management and sustainability. University of Lüneburg Working Paper Series in Economics, No. 248.

Rastogi, A., Hickey, G.M., Badola, R. \& Hussain, S.A. (2013) Diverging viewpoints on tiger conservation: a Q-method study and survey of conservation professionals in India. Biological Conservation, 161, 182-192.

Redpath, S.M., Arroyo, B., Leckie, F.M., Bacon, P., Bayfield, N., Gutiérrez, R.J. \& Thirgood, S.J. (2004) Using decision modeling with stakeholders to reduce human-wildlife conflict: a raptorgrouse case study. Conservation Biology, 18, 350-359.
Redpath, S.M., Bhatia, S. \& Young, J. (2015) Tilting at wildlife: reconsidering human-wildlife conflict. Oryx, 49, 222-225.

Rust, N.A. (2015a) Media framing of financial mechanisms for resolving human-predator conflict in Namibia. Human Dimensions of Wildlife, 20, 440-453.

Rust, N. A. (2015b) Understanding the human dimensions of coexistence between carnivores and people: a case study in Namibia. $\mathrm{PhD}$ thesis. University of Kent, Canterbury, UK.

RUST, N.A. \& MARKER, L.L. (2014) Cost of carnivore coexistence on communal and resettled land in Namibia. Environmental Conservation, 41, 45-53.

Schmolck, P. (2002) Http://schmolck.userweb.mwn.de/qmethod/ downpqwin.htm [accessed 6 December 2015].

Schumann, B., Walls, J.L. \& Harley, V. (2012) Attitudes towards carnivores: the views of emerging commercial farmers in Namibia. Oryx, 46, 604-613.

Selebatso, M., Moe, S.R. \& Swenson, J.E. (2008) Do farmers support cheetah Acinonyx jubatus conservation in Botswana despite livestock depredation? Oryx, 42, 430-436.

Skulmoski, G.J., Hartman, F.T. \& Krahn, J. (2007) The Delphi method for graduate research. Journal of Information Technology Education, 6, 1-21.

Stephenson, W. (1953) The Study of Behavior: Q-Technique and its Methodology. The University of Chicago Press, Chicago, USA.

Strauss, A. \& Corbin, J. (1990) Basics of Qualitative Research: Grounded Theory Procedures and Techniques. SAGE Publications, Thousand Oaks, USA.

SuRVEYMONKey (2015) Https://www.surveymonkey.com/ [accessed 6 December 2015].

Susskind, L., van der Wansem, M. \& Ciccareli, A. (2003) Mediating land use disputes in the United States: pros and cons. Environments, 31, 39-58.

Thirgood, S. \& Redpath, S.M. (2008) Hen harriers and red grouse: science, politics and human-wildlife conflict. Journal of Applied Ecology, 45, 1550-1554.

Webler, T., Danielson, S. \& Tuler, S. (2009) Using Q Method to Reveal Social Perspectives in Environmental Research. Social and Environmental Research Institute, Greenfield, USA.

Wieczorek Hudenko, H. (2012) Exploring the influence of emotion on human decision making in human-wildlife conflict. Human Dimensions of Wildlife, 17, 16-28.

Ziglio, E. (1996) The Delphi method and its contribution to decision-making. In Gazing into the Oracle: The Delphi Method and its Application to Social Policy and Public Health (eds M. Adler \& E. Ziglio), pp. 3-33. Jessica Kingsley Publishers, London, UK.

\section{Biographical sketch}

NIKI RUST's research focuses on carnivore conservation in unprotected areas and uses social science to understand how to improve coexistence between people and carnivores. 